\title{
Thraustochytrid and fungal component of marine detritus. III. Field studies on decomposition of leaves of the mangrove Rhizophora apiculata
}

\author{
Seshagiri Raghukumar*, Veena Sathe-Pathak, Sumita Sharma, \\ Chandralata Raghukumar
}

Biological Oceanography Division, National Institute of Oceanography, Dona Paula, Goa 403 004, India

\begin{abstract}
The sequence of colonisation, densities and biomass of fungi, thraustochytrid protists and bacteria during decomposition of leaves of the mangrove Rhizophora apiculata Blume, as well as the accompanying biochemical changes of the detritus, were studied in 2 litterbag experiments at Goa, India. Three phases were observed. (1) Thraustochytrids and the fungi Cladosporium herbarum and Halophytophthora vesicula colonised detritus during the first week, characterised by a rapid loss of detrital dry weight and a reduction in proteins, carbohydrates, reducing sugars, phenolics and cellulose. (2) Decline of most of the organic constituents in detritus to almost the lowest observed levels within $21 \mathrm{~d}$ was accompanied by an increase in fungal and bacterial biomass. Fungi and bacteria together contributed maxima of 0.052 and $0.065 \%$ to dry weight of 21 and 35 d detritus respectively. Protein values never increased with decomposition and microbial biomass buildup, although $\mathrm{C}: \mathrm{N}$ values declined. (3) Total fungal and bacterial biomass decreased after 3 and $5 \mathrm{wk}$, respectively. However, thraustochytrids and marine fungal species such as Cirrenalia basiminuta and 'Hyphomycete XVII' attained high densities by 56 to $60 \mathrm{~d}$. Most of the species present initially in the detritus were observed even in the last stages of decomposition examined ( 56 to $60 \mathrm{~d}$ ). Thraustochytrids and fungi were isolated both from surface-sterilized and untreated detritus, suggesting epi- and endobiontic modes of life. Distinct sequences of fungal and thraustochytrid colonisation, presence of high fungal biomass relative to bacterial biomass, the high densities of thraustochytrids and accompanying biochemical changes indicate the importance of these organisms in the mangrove detrital processes
\end{abstract}

KEY WORDS: Thraustochytrids · Fungi - Mangrove detritus

\section{INTRODUCTION}

Detritus derived from coastal marine macrophytes is colonised by bacteria (Pomeroy 1980, Bowen 1987, Peduzzi \& Herndl 1991), whose metabolic activities are important in the breakdown of the particulate detritus, as well as release and utilisation of dissolved organic matter (Koop et al. 1982, Hodson \& Moran 1989). Since bacterial biomass on detritus could serve as carbon and nitrogen sources in the nutrition of detritivores, and bacterially mediated biochemical transformations of detritus could render the refractory detritus more nutritional, these 2 aspects have been studied in great

\footnotetext{
•E-mail: raghu@bcgoa.ernet.in
}

detail (Newell \& Field 1983, Mann 1988, Pomeroy \& Wiebe 1988). However, the present consensus is that, except in certain cases (Kenworthy et al. 1989, Sathe \& Raghukumar 1991), microorganisms generally contribute less than $1 \%$ to detritus dry weight (Findlay \& Meyer 1984, Melillo et al. 1984, Bowen 1987, Blum et al. 1988). This has cast serious doubt on the importance of microbial biomass as food for metazoan detritivores (Bowen 1987, Blum et al. 1988, Kenworthy et al. 1989). In this context, a consideration of fungi and the fungilike unicellular osmoheterotrophic protists, the thraustochytrids (Moss 1986), would give a more complete picture of the microbial role in the detrital food web.

Several mycological studies on leaf- and seedlingderived detritus in subtropical mangroves have eluci- 
dated species composition and succession (mycoseres) and abundance of thraustochytrids (Newell 1976, Fell \& Master 1980, Nakagiri et al. 1989), as well as fungal colonisation and biochemical changes (Cundell et al. 1979). However, similar studies on tropical mangroves are few. In addition, information on fungal biomass and their fluctuations in mangrove detritus is meagre (Blum et al. 1988). Data on the biochemical composition of mangrove detritus accompanying mycoseres and fungal biomass which might provide clues on the role of fungi in these substrata are not available as they are for bacteria

In this paper, we address the following problems concerning leaf detritus of the mangrove Rhizophora apiculata Blume: (1) the densities and biomass of thraustochytrids and fungi in different decompositional stages, with relation to bacteria; (2) the sequence of colonisation of fungal species with progress of decomposition; and (3) the broad biochemical changes which accompany the above.

\section{MATERIALS AND METHODS}

The experiments were carried out at Chorao mangrove in Goa, India $\left(15^{\circ} 27^{\prime}\right.$ to $15^{\circ} 38^{\prime} \mathrm{N}, 73^{\circ} 42^{\prime}$ to $75^{\circ} 50^{\prime} \mathrm{E}$ ), situated about $8 \mathrm{~km}$ upstream from the mouth of the Mandovi river to the Arabian Sea.

Litterbag experiments. Two litterbag experiments were carried out: 5 December 1988 to 3 February 1989 (Expt 1) and 8 November 1989 to 3 January 1990 (Expt 2). The water temperature during these periods varied from 25 to $30^{\circ} \mathrm{C}$ and salinity from 25 to $30 \%$. Nylon litter bags of $1 \mathrm{~mm}$ mesh, measuring $1 \times 0.25 \mathrm{~m}$ and divided into 4 pouches, were used. Two yellow, senescent leaves of Rhizophora apiculata plucked from the trees were placed in each pouch of the bag $(8$ leaves per bag). Fifteen such bags, with a total of 120 leaves, were attached to a plastic frame and placed in a creek in the mangrove below low tide level. One or two bags were removed at intervals of 4 to $7 \mathrm{~d}$, for a total period of 60 and $56 \mathrm{~d}$ in Expts 1 and 2 respectively, and brought to the laboratory for analysis.

Isolation and enumeration of fungi and thraustochytrids. Discs of $5 \mathrm{~mm}$ diameter from the detritus were used directly or following surface-sterilization with a $0.5 \%$ sodium hypochlorite solution (Newell \& Fell 1982). Twenty discs were homogenised in $15 \mathrm{ml}$ of sterile seawater. Aliquots of $0.1 \mathrm{ml}$ were plated onto 5 Petri plates with Corn Meal Agar made up of $50 \%$ seawater or a 'thraustochytrid medium' [glucose $0.01 \%$, peptone $0.01 \%$, yeast extract $0.05 \%$, vitamin mix according to Vishniac (see Jones 1971), agar 1.2\%, seawater $100 \mathrm{ml}$. The media contained $0.05 \mathrm{~g}$ streptomycin and 10000 units penicillin per $100 \mathrm{ml}$. After incubation for 1 wk at room temperature, mean numbers of colonies of thraustochytrids and tentatively identified individual species of fungi for the different media and treatments were recorded. These values were converted to mean numbers per g dry wt detritus based on that of a leaf disc. From among the fungal species growing out of non-surface-sterilized material, only those which were also observed on surface-sterilized ones were taken into account, since the others might have arisen from spore contaminants. From among the 2 media and treatments, the highest mean numbers of such individual species were pooled and expressed as total derived numbers.

Thraustochytrids were also enumerated by using the pine pollen baiting/MPN method of Gaertner (1968), in which $1.0,0.5,0.25,0.1$ and $0.05 \mathrm{ml}$ of the homogenates of surface-sterilized and non-surfacesterilized detritus were added to $5 \mathrm{ml}$ of sterile seawater in $20 \mathrm{ml}$ flat-bottomed screw-cap tubes and baited with sterilised pine pollen. Numbers per $\mathrm{ml}$ of homogenate were estimated using Thomas' formula (American Public Health Association 1981) and converted to numbers per $g$ detritus based on the dry weight material present in $1 \mathrm{ml}$ suspension.

Fungi were also isolated by moist-chamber (Kohlmeyer \& Kohlmeyer 1979) and sterile-seawater (Newell \& Fell 1980) incubations.

Biomass estimations. All estimations were carried out with material fixed in $3 \%$ formalin. Biomass of mycelial fungi was estimated after clearing the detrital material with $\mathrm{KOH}$ and hydrogen peroxide and staining for hyphae with lactophenol-cotton blue (Koske \& Gemma 1989). Total length and average widths of hyphae were measured in 5 sets of 10 random microscopic fields (total of 50) for each detrital sample. The mean of the 5 sets was converted to biovolume, considering the hyphae as cylinders. Biomass was derived from biovolumes using a conversion factor of $200 \mathrm{mg}$ dry wt $\mathrm{cm}^{-3}$ fungus (Newell et al. 1986).

Mean numbers of bacteria were estimated from 5 sets of 10 microscope fields as above using the Acridine Orange Direct Count (AODC) method (Parsons et al. 1984). The values were converted to bacterial carbon using a factor of $20 \mathrm{fg}$ per bacterial cell (Peduzzi \& Herndl 1991), and a factor of 2 was used to convert bacterial carbon to dry wt (Blum et al. 1988).

Biochemical analyses. Proteins were estimated using the modification of Lowry's method (Peterson 1977), reducing sugars by the DNS method (Miller 1960) and carbohydrates as described by Dawes (1981). Total phenols were extracted in methanol overnight and spectrophotometrically estimated using Folin Denis reagent (Swain \& Hillis 1959). Lignin and cellulose were estimated gravimetrically following Allen (1974). Ash content was determined as loss of 
weight after heating at 450 to $500^{\circ} \mathrm{C}$ for $5 \mathrm{~h}$. Total $\mathrm{C}$ and $\mathrm{N}$ were analysed using a Heraeus CHN.O Rapid Analyser at the Indian Institute of Technology, Madras.

We have expressed the amounts of various organic constituents in detritus as (1) percentages of ash-free dry weight (AFDW) and (2) percentages of dry weight detritus, as has been conventionally done in literature. However, fresh detritus gradually loses weight through leaching of soluble organics and a given area of detritus weighs much less during later stages of decomposition than at the beginning. Therefore, the changes in detritus cannot be related to the original material in terms of weight, but only as values normalised to a parameter which remains constant. Assuming that no substantial additions or removal of minerals from detrital material occurs, we have presented values of the detrital organic constituents (a) as those normalised to the original ash content using the following formula:

$$
\begin{aligned}
& \begin{array}{l}
\text { Normalised } \\
\text { value of } a \\
\text { in detritus }
\end{array} \\
& \begin{array}{c}
\% \text { ash in detritus } \\
\text { on Day } x
\end{array}
\end{aligned} \times \begin{aligned}
& \% \text { a in in detritus } \\
& \text { on Day } x
\end{aligned}
$$

\section{RESULTS}

\section{Sequences of colonisation}

Three distinct sequences were observed.

(1) Senescent, attached leaves (0 d) harboured yeasts, and terrestrial species of fungi such as Fusarium moniliforme Sheld., and non-sporulating species in Expt 1 (Table 1) and species of Acremonium and Aspergillus, Cladosporium herbarum (Pers.) Link ex Gray, F. moniliforme and non-sporulating species in Expt 2 (Table 2). All these species persisted in detritus up to the last stage of decomposition examined (56 and $60 \mathrm{~d}$ ) or reappeared then.

(2) The first samplings carried out after submergence of leaves ( 4 and 7 d) yielded Cladosporium herbarum in Expt 1 (Table 1), the oomycete Halophytophthora vesicula (Anast. et Church) Ho et Jong in Expt 2 (Table 2) and thraustochytrid protists in both experiments. Labyrinthula sp. was recorded after 53 and $14 \mathrm{~d}$ respectively (Tables 1 \& 2). These species also persisted until the end of the study period. $H$. vesicula and thraustochytrids attained peak densities by 56 to $60 \mathrm{~d}$

Table 1 Rhizophora apiculata. Densities of fungi in decomposing mangrove leaves (no. $g^{-1}$ dry wt). Expt 1

\begin{tabular}{|c|c|c|c|c|c|c|c|c|c|}
\hline \multirow[t]{2}{*}{ Species } & \multicolumn{9}{|c|}{ Age of detritus (d) } \\
\hline & 0 & 4 & 7 & 14 & 21 & 28 & 46 & 53 & 60 \\
\hline Acremonium sp. & 0 & 0 & 3500 & 0 & 0 & 0 & 5500 & 0 & 0 \\
\hline Aspergillus spp. & 0 & 0 & 1200 & 0 & 0 & 0 & 0 & 0 & 24000 \\
\hline Cladosporium herbarum & 0 & 63300 & 44600 & 158000 & 16600 & 12900 & 7370 & 3690 & 475000 \\
\hline Cirrenalia basiminuta & 0 & 0 & 0 & 0 & 0 & 0 & 16600 & 22100 & 0 \\
\hline Fusarium moniliforme & 173000 & 0 & 0 & 0 & 0 & 0 & 0 & 0 & 5530 \\
\hline 'Hyphomycete XVII' & 0 & 0 & 0 & 0 & 11100 & 10600 & 81100 & 103000 & 0 \\
\hline Labyrinthula spp. & 0 & 0 & 0 & 0 & 0 & 0 & 0 & 5530 & 0 \\
\hline Non-sporulating forms & 12900 & 15200 & 11700 & 31300 & 18400 & 20300 & 47900 & 88500 & 12900 \\
\hline Penicillium sp. & 759 & 4690 & 1170 & 0 & 0 & 0 & 3690 & 0 & 14700 \\
\hline Yeasts & 7590 & 7040 & 7040 & 1633000 & 12900 & 5530 & 0 & 1840 & 5530 \\
\hline
\end{tabular}

Table 2. Rhizophora apiculata. Densities of fungi in decomposing mangrove leaves (no. $\mathrm{g}^{-1} \mathrm{dry}$ wt). Expt 2

\begin{tabular}{|c|c|c|c|c|c|c|c|c|c|}
\hline \multirow[t]{2}{*}{ Species } & \multicolumn{9}{|c|}{ Age of detritus (d) } \\
\hline & 0 & 7 & 14 & 21 & 28 & 35 & 42 & 49 & 56 \\
\hline Acremonium sp. & 2610 & $0^{\mathrm{a}}$ & 2860 & $6350^{\mathrm{a}}$ & $25400^{a}$ & 28600 & 19000 & $2860^{a}$ & 2860 \\
\hline Aspergillus spp. & 2610 & 0 & 0 & 0 & $2860^{\mathrm{a}}$ & 19000 & 0 & 0 & 19000 \\
\hline Cladosporium herbarum & 2610 & 303000 & 44400 & 2860 & 12700 & 12700 & 19000 & 25400 & 31700 \\
\hline Cirrenalia basiminuta & 0 & $0^{\mathrm{a}}$ & $0^{\mathrm{a}}$ & $0^{\mathrm{a}}$ & 6350 & $5720^{\mathrm{a}}$ & $4290^{\mathrm{a}}$ & 12700 & 25400 \\
\hline Fusarium moniliforme & 2610 & 4040 & 0 & 12700 & 0 & 0 & 0 & 0 & 0 \\
\hline Halophytophthora vesicula & 0 & $7830^{\mathrm{a}}$ & $0^{\mathrm{a}}$ & $0^{\mathrm{a}}$ & 0 & $6350^{\mathrm{a}}$ & $5720^{a}$ & 7150 & 7150 \\
\hline 'Hyphomycete XVII' & 0 & 0 & $0^{a}$ & $6350^{\mathrm{a}}$ & $19000^{\mathrm{a}}$ & 8670 & $7150^{\mathrm{a}}$ & $12700^{\mathrm{a}}$ & $19000^{\mathrm{a}}$ \\
\hline Labyrinthula spp. & 0 & 0 & 2860 & 635000 & 0 & 0 & 1430 & 793000 & 0 \\
\hline Lulworthia sp. & 0 & 0 & $0^{\mathrm{a}}$ & 0 & $0^{\mathrm{a}}$ & $0^{\mathrm{a}}$ & 0 & 0 & 0 \\
\hline Non-sporulating forms & 22300 & 23300 & 12700 & 5720 & 19000 & 12700 & 19000 & 25400 & 44400 \\
\hline Yeasts & 0 & 0 & 0 & $6350^{\mathrm{a}}$ & 0 & 6350 & 0 & 6350 & 0 \\
\hline
\end{tabular}


(3) The obligate marine species Cirrenalia basiminuta Raghukumar et Zainal and an unidentified hyphomycete (termed 'Hyphomycete XVII' in the text) were recorded only after $21 \mathrm{~d}$ using the plating technique, attaining peak densities in the last stages of decomposition (Tables 1 \& 2). However, moist-chamber and seawater incubation yielded these 2 species, as well as the marine ascomycete Lulworthia sp., even after $7 \mathrm{~d}$ (Table 2 ).

\section{Densities of thraustochytrids and biomass of fungi and bacteria}

Thraustochytrids were recovered from non-surfacesterilized as well as surface-sterilized detritus using plating and baiting techniques (Figs, 1 \& 2). Numbers of up to $25 \times 10^{3}$ and $28 \times 10^{3} \mathrm{~g}^{-1}$ dry wt detritus were detected in the 2 experiments using the former. How ever, the baiting technique yielded thraustochytrids more consistently (Fig. 1). Fungi contributed 0.002 to $0.014 \%$ to the detrital dry wt in Expt 1 (Fig. 3). Their

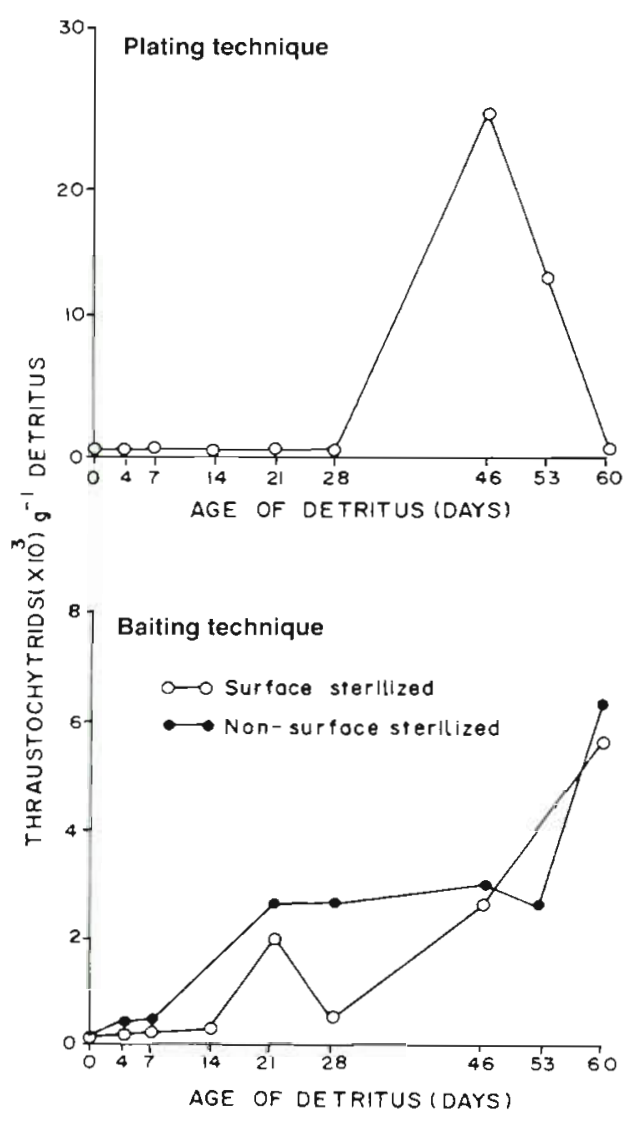

Fig. 1 Rhizophora apiculata. Densities of thraustochytrids in decomposing mangrove leaves, estimated by culture techniques. Expt 1 biomass was higher in Expt 2 (0.017 to $0.052 \%$ of the detrital dry wt). Maximum biomass in both the experiments occurred in $21 \mathrm{~d}$ detritus. There was an almost linear increase of fungal biomass in Expt 2, starting from $0 \mathrm{~d}$ (Fig. 3). A second, smaller biomass peak was observed in 42 or $46 \mathrm{~d}$ detritus. Bacteria were not detected on attached, senescent leaves ( 0 d detritus). Bacterial biomass in Expt 2 was less than that of the fungi up to $21 \mathrm{~d}$, but increased later (see Fig. 6). The maximum bacterial biomass of $0.0624 \%$ was attained at $35 \mathrm{~d}$ (Fig. 4).

\section{Biochemical changes}

Decaying leaves showed a rapid loss of dry wt, attaining $66 \%$ of original values in $7 \mathrm{~d}$ and $50 \%$ by $14 \mathrm{~d}$. No marked change was observed after this (Fig. 5). Substantial decline in reducing sugars, carbohydrates, total phenols and proteins occurred within $21 \mathrm{~d}$ of submergence (Figs. $5 \& 6$ ). The former was lost more rapidly, reaching minimal values in $14 \mathrm{~d}$. In con-

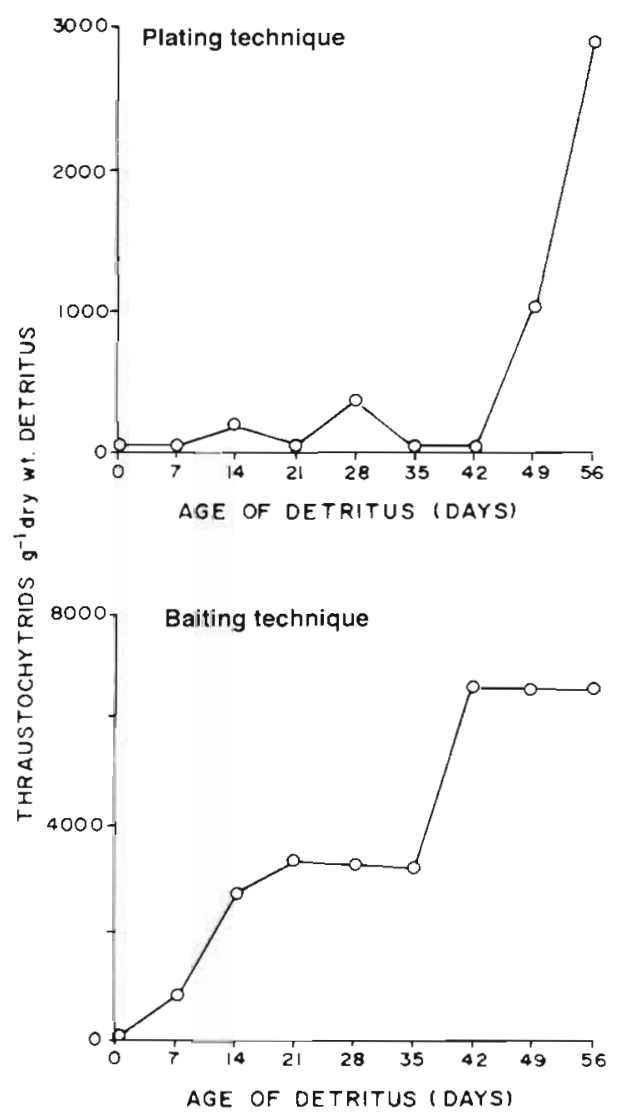

Fig. 2. Rhizophora apiculata. Densities of thraustochytrids in decomposing mangrove leaves, estimated by culture techniques. Expt 2 


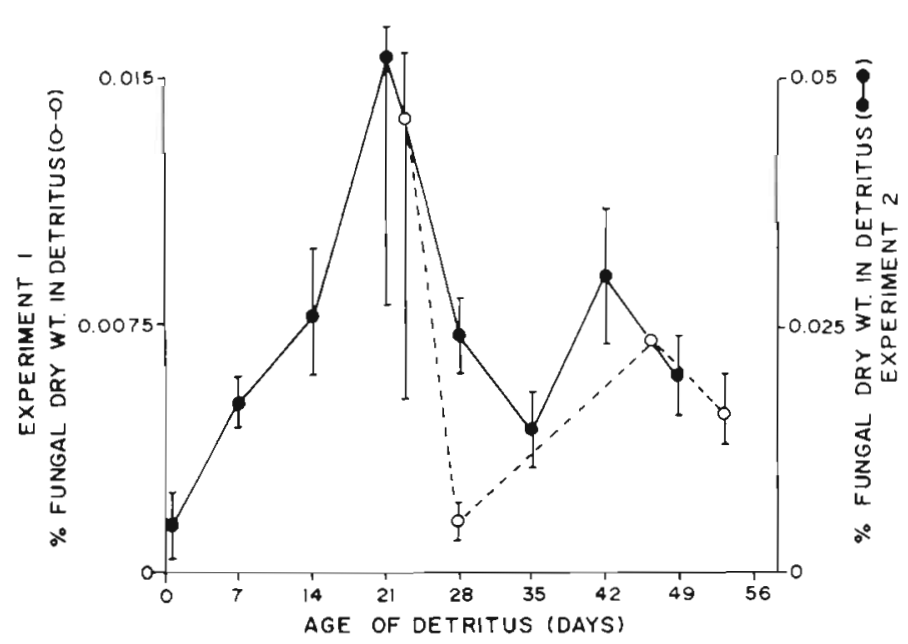

Fig. 3. Rhizophora apiculata. Fungal biomass in decomposing mangrove leaves

trast, loss of carbohydrates was more gradual up to $60 \mathrm{~d}$ (Fig. 5). Proteins decreased further after $21 \mathrm{~d}$, reaching minimal values within $60 \mathrm{~d}$ (Fig. 5). Cellulose and lignin contents showed a steady decline with age in terms of normalised values, but not as percentages of AFDW or dry weight (Fig. 6). C/N ratios of senescent leaves decreased from 31 in $0 \mathrm{~d}$ detritus to $12 \mathrm{in} 60 \mathrm{~d}$ detritus (Fig. 6)

\section{DISCUSSION}

The sequence of colonisation of thraustochytrids and fungi, biomass buildup of fungi and densities of thraus-

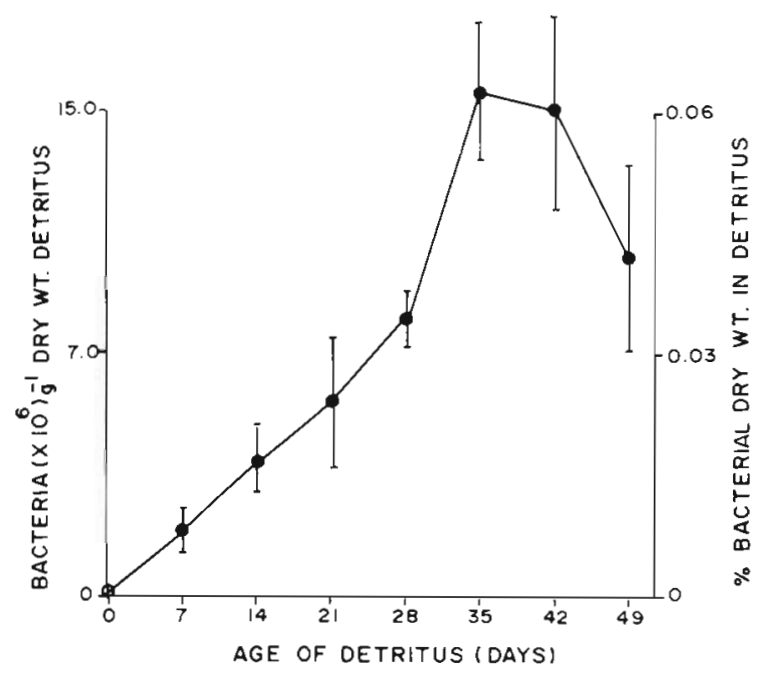

Fig. 4. Rhizophora apiculata. Bacterial densities and biomass in decomposing mangrove leaves. Expt 2 tochytrids on submerged mangrove leaves appears to be related to the 3 well-recognized phases of macrophytic decomposition (Godschalk \& Wetzel 1978, Valiela et al. 1984) (Table 3).

(1) The initial leaching phase, in which soluble organics are rapidly lost and detrital dry weight decreases (up to $7 \mathrm{~d}$ in our experiments; Fig. 5), may be characterised by colonisation of thraustochytrids and fungi such as Halophytophthora vesicula and Cladosporium herbarum (Tables 1 \& 3). These organisms may ecologically resemble bacteria at this stage by way of responding rapidly to the leaching nutrients in terms of metabolism and growth (Blum \& Mills 1991, Peduzzi \& Herndl 1991). They may also be more tolerant of the higher levels of phenolics in such detritus (Fig. 6), which are generally known to be inhibitory to microbial growth (Cundell et al. 1979, Gonzalez-Farias \& Mee 1988). The earliest samplings that revealed their presence were carried out only 4 to $7 \mathrm{~d}$ after submergence of the leaves. However, it is likely that these species colonise detritus even earlier, as is known from subtropical mangroves (Newell 1976, Fell \& Master 1980, Newell et al. 1987). Indeed, $H$. vesicula may colonise fallen mangrove leaves within $24 \mathrm{~h}$, attain $100 \%$ frequency of isolation in $30 \mathrm{~h}$ and totally pervade the detrital tissue (Newell et al. 1987). In addition to the above organisms, terrestrial species of fungi (geofungi) that were present even on senescent leaves attached to the trees and which were also isolated from submerged ones (Table 1) might have been involved in the initial phases of detrital dynamics.

(2) Attainment of peak fungal biomass and an increase in total microbial biomass characterize the period from 7 to $21 \mathrm{~d}$, when a rapid decline of proteins, carbohydrates, reducing sugars and phenols, as well as cellulose, took place (Figs. 3 to 6 ). This corresponds to the second decompositional phase of detritus which normally lasts from a few days to a few weeks (Godschalk \& Wetzel 1978, Valiela et al. 1984) and results in high bacterial assimilation efficiencies and turnover times (Blum \& Mills 1991). Fungal biomass peaked at the end of this period (Fig. 3). Contrary to our results, Cundell et al. (1979) observed scant fungal hyphae in decomposing mangrove leaves up to $28 \mathrm{~d}$. This difference might be attributed to the fact that these authors, using scanning electron microscopy, observed only the hyphae on detrital surface, and not the pervading ones. Our microscopic technique enabled us to look for both epi- and endobiontic hyphae (see also Sathe \& Raghukumar 1990).

Increase in microbial biomass resulted in the buildup of total organic nitrogen content and a lower C:N ratio, 

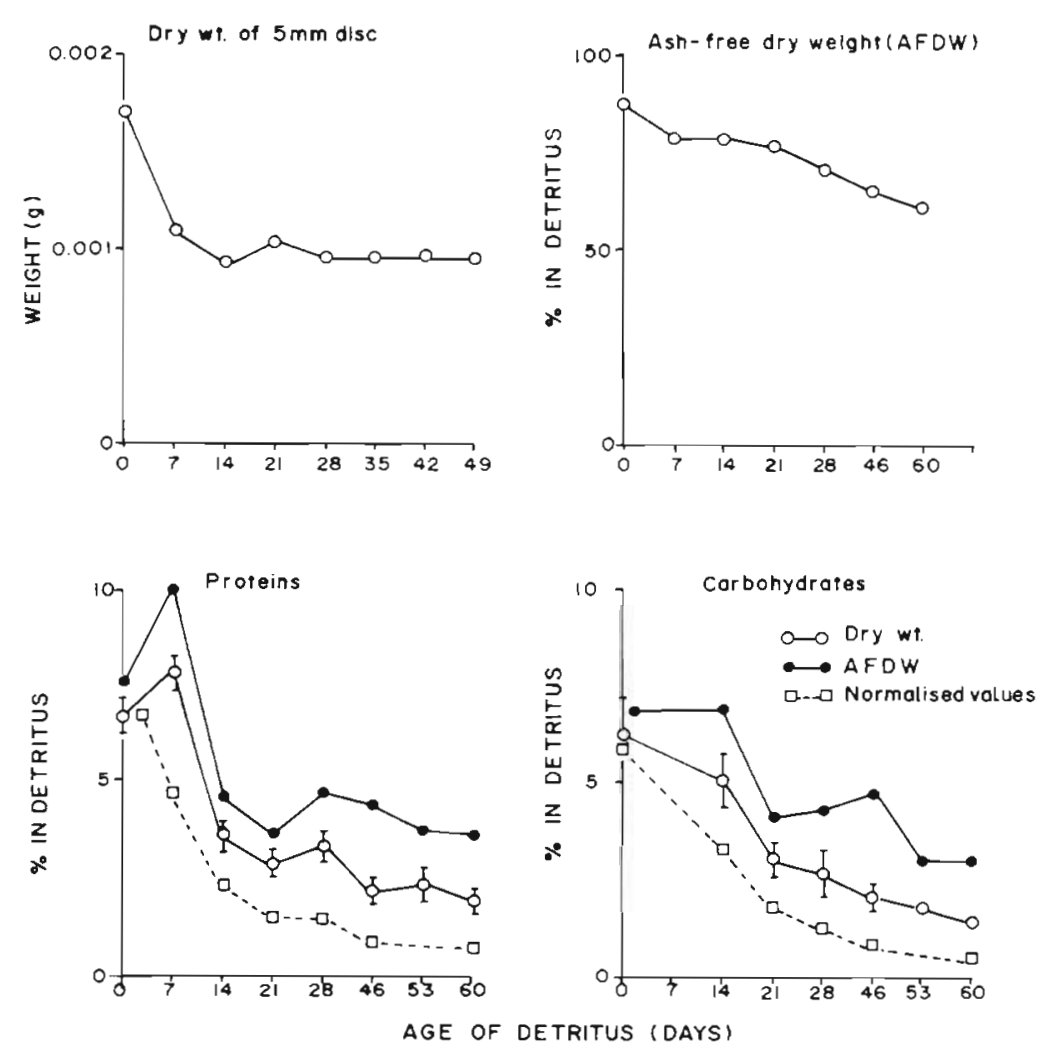

Fig. 5. Rhizophora apiculata. Biochemical changes during decomposition of mangrove leaves. Expt 2

but not in an enhancement of protein levels (Figs. 5 $\& 6)$. Such increases in non-protein nitrogen have been attributed to the complexing of microbial enzymes and other exudates, such as mucopolysaccharides, with carbohydrates and phenolics, resulting in recalcitrant humic nitrogen (Rice 1982, Rublee \& Roman 1982, Melillo et al. 1984, Wilson et al. 1986, Sathe-Pathak et al. 1993).
(3) The third phase, following $21 \mathrm{~d}$ of decomposition, during which the substrate had become depleted in nutrients and phenolics, appears to be characterised by an increase in densities of marine species such as Cirrenalia basiminuta and 'Hyphomycete XVII'. These may, however, colonise detritus much earlier ( $7 \mathrm{~d}$ in Expt 2; Table 2). Such species may either have a slow rate of biomass buildup or an intolerance to the high levels of phenolics in early stages. The high densities attained by these species as well as thraustochytrids in late stages of this third phase of decomposition, and a further decline in cellulose and lignin during this period, indicate an active role for these organisms in the recalcitrant detritus. Although cellulases and other enzymes capable of degrading complex polysaccharides have not been demonstrated in Halophytophthora vesicula and thraustochytrids (Bahnweg 1978, 1979), this aspect may need further examination.

The attainment of peak bacterial biomass by $35 \mathrm{~d}$ in this study, much later than in the case of fungi, is similar to results obtained for seagrass and mangrove leaf detritus by Rublee \& Roman (1982), Blum et al. (1988), and Robertson (1988). These authors observed maximum bacterial standing crops after 35 to $40 \mathrm{~d}$ of decomposition. Rublee \& Roman (1982) contended that bacteria may play important roles in both the early and late stages of decomposition, while fungi may predominate in the intermediate stages. Blum et al. (1988) sug-

Table 3. Rhizophora apiculata. Major events during colonization of decomposing mangrove leaves by thraustochytrids and fungi

\begin{tabular}{|c|c|c|c|}
\hline Event & Age of detritus & Thraustochytrids and fungi & Biochemical changes \\
\hline 1 & $0 \mathrm{~d}$ : Senescent, attached leaves & $\begin{array}{l}\text { Phylloplane fungi present; } \\
\text { few bacteria; low microbial } \\
\text { biomass }\end{array}$ & $\begin{array}{l}\text { High amounts of all organic } \\
\text { constituents }\end{array}$ \\
\hline 2 & $0-7 \mathrm{~d}$ after submergence & $\begin{array}{l}\text { Colonization by Halophytophthora } \\
\text { vesicula and thraustochytnds; low } \\
\text { microbial biomass }\end{array}$ & $\begin{array}{l}\text { Rapid loss of dry wt; leaching } \\
\text { of proteins, carbohydrates, } \\
\text { reducing sugars and phenolics }\end{array}$ \\
\hline 3 & $7-21 \mathrm{~d}$ after submergence & $\begin{array}{l}\text { Rapid increase in fungal and } \\
\text { bacterial biomass; peak fungal } \\
\text { biomass }\end{array}$ & $\begin{array}{l}\text { Rapid decline of proteins, } \\
\text { carbohydrates, reducing } \\
\text { sugars, phenolics and cellulose }\end{array}$ \\
\hline 4 & $21-60 \mathrm{~d}$ after submergence & $\begin{array}{l}\text { Peak bacterial biomass by } 35 \mathrm{~d}_{\text {i }} \\
\text { subsequent decline of fungal and } \\
\text { bacterial biomass; high densities of } \\
\text { marine fungi and thraustochytrids }\end{array}$ & $\begin{array}{l}\text { Further decline of cellulose } \\
\text { and lignin }\end{array}$ \\
\hline
\end{tabular}



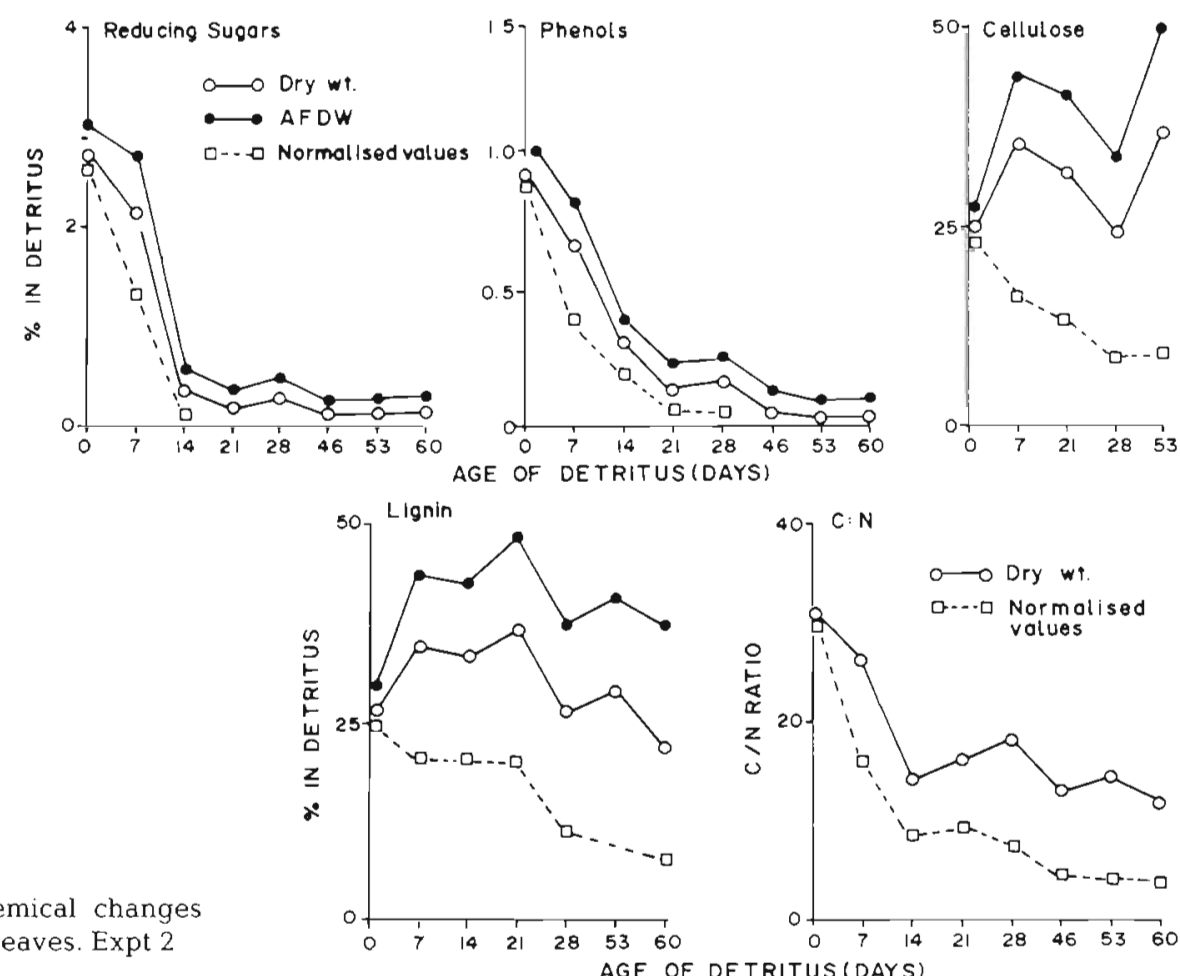

Fig. 6. Rhizophora apiculata. Biochemical changes during decomposition of mangrove leaves. Expt 2 gested that bacteria are likely to predominate during later stages of decomposition when the detritus is refractory.

According to this study, peak fungal biomass in mangrove leaf detritus was $80 \%$ of the highest bacterial biomass, in contrast to the observations of Blum et al. (1988), who reported the maximum fungal contribution to total microbial biomass to be only $20 \%$. This might be attributable to the technique we employed in estimating fungal biomass, whereby we used unhomogenised detritus for staining and fungal detection in contrast to the Mollison's technique employed by Blum et al. (1988) (see Sathe \& Raghukumar 1991 for discussion). Therefore, fungi may form a significant component of the total microbial biomass in mangrove detritus. However, we observed maximum biomass values of only 0.052 and $0.065 \%$ for fungi and bacteria, while Blum et al. (1988) reported 0.1 and $0.68 \%$ biomass for the 2 groups respectively in mangrove leaf detritus. The maximum combined fungal and bacterial biomass was only 0.076 to $0.077 \%$ of detrital dry wt after 21 and $35 \mathrm{~d}$. Reasons for this discrepancy could be: (1) the geographical location and environmental characteristics of the 2 sampling sites; and (2) more vigorous microbial grazing by protozoans and nematodes in our samples.

Beside fungal and bacterial biomass, 3 further points will have to be considered in the future. (1) Microbial biomass may actually be greater than what is so far recognized, if thraustochytrids and yeasts are taken into account. Thraustochytrids in brown algal detritus amounted to $0.065 \% \mathrm{C}$ of detrital dry wt $(0.13 \%$ dry wt biomass if $\mathrm{C}$ to dry wt is assumed to be 0.5) (SathePathak et al. 1993). Application of a newly developed epifluorescence technique for biomass estimations of thraustochytrids (Raghukumar \& Schaumann 1993) might shed more light on this. Biomass studies on yeasts in marine detritus are few, essentially due to the lack of an adequate technique. These might make a significant contribution to microbial biomass as in the 14 d detritus of Expt 1, where an apparent yeast bloom occurred (Table 1). Meyers (1974) reported similar blooms in decaying Spartina alterniflora Loisel. (2) More important than biomass per se might be the possible supply of essential nutrients such as fatty acids, sterols, vitamins and other growth factors to detritivores (Phillips 1984). The recent finding of high contents of polyunsaturated fatty acids (PUFAs) in thraustochytrids by Findlay et al. (1986), which appear to be important in reproduction of crustaceans (Harrison 1990), lends further credence to this. (3) The actual significance of fungi and thraustochytrids in terms of degradation and flux of dissolved and particulate organic matter will have to be examined.

Acknowledgements. This work was funded by the Department of Environment, Government of India, to whom V.S.-P. and S.S. are grateful for awards of Senior Research Fellowships. The authors thank Dr D. Chandramohan and Dr A. H. 
Parulekar for encouragement and suggestions. The help of Prof. G. N. Swamy, Indian Institute of Technology, Madras, and Dr A. Ramesh, Physical Research Laboratory, Ahmedabad, in $\mathrm{C} / \mathrm{N}$ analyses is gratefully acknowledged.

\section{LITERATURE CITED}

Allen SE (ed) (1974) Analyses of ecological materials. Blackwell Scientific Publications, Oxford

American Public Health Association (1981) Standard methods for the examination of water and wastewater. APHA, Washington, DC

Bahnweg G (1978) Physiology of Peronosporales (Phytophthora spp. and Pythium sp.) associated with decay of leaf litter in marine environments. Veröf Inst Meeresforsch Bremerhaven 17:33-44

Bahnweg G (1979) Studies on the physiology of Thraustochytriales. II. Carbon nutrition of Thraustochytrium spp., Schizochytrium sp., Japonochytrium sp., Ulkenia spp. and Labyrinthuloides spp. Veröff Inst Meeresforsch Bremerhaven 17:269-273

Blum LK, Mills AL (1991) Microbial growth and activity during the initial stages of seagrass decomposition. Mar Ecol Prog Ser 70:73-82

Blum LK, Mills AL, Zieman JC, Zieman RT (1988) Abundance of bacteria and fungi in seagrasses and mangrove detritus. Mar Ecol Prog Ser 42:73-78

Bowen SH (1987) Composition and nutritional value of detritus. In: Moriarty DJW, Pullin RSV (eds) Detritus and microbial ecology in aquaculture. International Center for Living Aquatic Resources Management, Manila, p $192-216$

Cundell AM, Brown MS, Stanford R, Mitchell R (1979) Microbial degradation of Rhizophora mangle leaves immersed in the sea. Estuar coast Shelf Sci 9:281-286

Dawes CJ (1981) Marine botany. John Wiley \& Sons, New York

Fell JW, Master IM (1980) The association and potential role of fungi in mangrove detrital systems. Botanica mar 23: $256-263$

Findlay RH, Fell JW, Coleman NK, Vestal JR (1986) Biochemical indicators of the role of fungi and thraustochytrids in mangrove detrital systems. In: Moss ST (ed) The biology of marine fungi. Cambridge University Press, Cambridge, p $91-104$

Findlay S, Meyer JL (1984) Significance of bacterial biomass and production as an organic carbon source in lotic detrital systems. Bull mar Sci 35:318-325

Gaertner A (1968) Eine Methode des quantitativen Nachweises niederer mit Pollen köderbarer Pilze im Meerwasser und im Sediment. Veröff Inst Meeresforsch Bremerhaven Sonderb 3:75-92

Godschalk GL, Wetzel RG (1978) Decomposition of aquatic angiosperms. III. Zostera marina L and a conceptual model of decomposition. Aquat Bot 5:329-354

Gonzalez-Farias F, Mee LD (1988) Effect of mangrove humiclike substances on biodegradation rate of detritus. J exp mar Biol Ecol 119:1-13

Harrison KE (1990) The role of nutrition in maturation, reproduction and embryonic development of decapod crustaceans: a review. J Shellfish Res 9:1-28

Hodson RE, Moran MA (1989) Microbial transformation of mangrove detritus: fate of soluble, structural lignocellulosic components. In: Hattori T, Ishida $Y$, Maruyama $Y$, Morita RY, Uchida A (eds) Recent advances in microbial ecology. Japan Scientific Press, Tokyo, p 287-291
Jones EBG (1971) Aquatic fungi. In: Booth C (ed) Methods in microbiology. Academic Press, London, p 335--365

Kenworthy W, Currin CA, Fonseca M, Smith G (1989) Production, decomposition and heterotrophic utrlisation of the seagrass Halophila decipiens in a submarine canyon. Mar Ecol Prog Ser 51:277-290

Kohlmeyer J, Kohlmeyer E (1979) Marine mycology. The higher fungi. Academic Press, New York

Koop K, Newell RC, Lucas MI (1982) Microbial regeneration of nutrients from the decomposition of macrophyte debris on the shore. Mar Ecol Prog Ser 9:91-96

Koske RE, Gemma JN (1989) A modified procedure for staining roots to detect VA mycorrhizae. Mycol Res 92:486-488

Mann KH (1988) Production and use of detritus in various freshwater, estuarine and coastal marine ecosystems. Limnol Oceanogr 33:910-930

Melillo JM, Naiman RJ, Aber JD, Linkins AE (1984) Factors controlling mass loss and nitrogen dynamics of plant litter decaying in northern streams. Bull mar Sci 35:341-356

Meyers SP (1974) Contribution of fungi to biodegradation of Spartina and other brackish marshland vegetation. Veröft Inst Meeresforsch Bremerhaven Suppl 5:357-375

Miller GL (1960) Use of dinitrosalicylic acid reagent for determination of reducing sugars. Analyt Chem 37:426-428

Moss ST (1986) Biology and phylogeny of the Labyrinthulales and Thraustochytriales. In: Moss ST (ed) The biology of marine fungi. Cambridge University Press, Cambridge, p $105-130$

Nakagiri A, Tokumasu $\mathrm{S}$, Araki $\mathrm{H}$, Koreeda S, Tubaki $\mathrm{K}$ (1989) Succession of fungi in decomposing mangrove leaves in Japan. In: Hattori $T$, Ishida $Y$, Maruyama $Y$, Morita RY, Uchida A (eds) Recent advances in microbial ecology. Japan Scientific Press, Tokyo, p 297-301

Newell RC, Field JG (1983) The contribution of bacteria and detritus to carbon and nitrogen flow in a benthic community. Mar Biol Lett 4:23-36

Newell SY (1976) Mangrove fungi: the succession in the mycoflora of red mangrove (Rhizophora mangle L.) seedlings. In: Jones EBG (ed) Recent advances in aquatic mycology. Elek Science, London, p 51-91

Newell SY, Fallon RD, Miller JD (1986) Measuring fungal biomass dynamics in standing dead leaves of a salt marsh vascular plant. In: Moss ST (ed) The biology of marine fungi. Cambridge University Press, Cambridge, p 19-25

Newell SY, Fell JW (1980) Mycoflora of turtlegrass (Thalassia testudinum König) as recorded after seawater incubation. Botanica mar 23:265-275

Newell SY, Fell JW (1982) Surface sterilization and the active mycoflora of leaves of a seagrass. Botanica mar 25 $339-346$

Newell SY, Miller JD, Fell JW (1987) Rapid and pervasive occupation of fallen mangrove leaves by a marine zoosporic fungus. Appl environ Nicrobiol 53.2464-2469

Parsons TR, Maita Y, Lalli CM (1984) A manual of chemical and biological methods for seawater analysis. Pergamon Press, Oxford

Peduzzi P. Herndl GJ (1991) Decomposition and sıgnificance of seagrass leaf litter (Cymodocea nodosa) for the microbial food web in coastal waters (Gulf of Trieste, Northern Adriatic Sea). Mar Ecol Prog Ser 71:163-174

Peterson GL (1977) A simplification of the protein assay method of Lowry et al. which is more generally applicable. Analyt Biochem 83:346-356

Phillips NW (1984) Role of different microbes and substrates as potential supplies of specific, essential nutrients to marine detritivores. Bull mar Sci 35:283-298

Pomeroy LR (1980) Detritus and its role as a food source. In: 
Barnes RSK, Mann KH (eds) Fundamentals of aquatic ecosystems. Blackwell Scientific Publications, Oxford, p $84-102$

Pomeroy LR, Wiebe WJ (1988) Energetics of microbial foodwebs. Hydrobiologia 159:7-18

Raghukumar S, Schaumann K (1993) An epifluorescence microscopy method for direct detection and enumeration of the fungilike marine protists, the thraustochytrids. Limnol Oceanogr 38:182-187

Rice DL (1982) The detritus nitrogen problem: new observations and perspectives from organic geochemistry. Mar Ecol Prog Ser 9:153-162

Robertson AI (1988) Decomposition of mangrove leaf litter in tropical Australia. J exp mar Biol Ecol 116:235-247

Rublee PA, Roman MR (1982) Decomposition of turtlegrass (Thalassia testudinum König) in flowing seawater tanks and litterbags: compositional changes and comparison with natural particulate matter. J exp mar Biol Ecol 58: $47-58$
Sathe V, Raghukumar S (1991) Fungi and their biomass in detritus of the seagrass Thalassia hemprichii (Ehrenberg) Ascherson. Botanica mar 34:272-277

Sathe-Pathak V, Raghukumar S, Raghukumar C, Sharma S (1993) Thraustochytrid and fungal component of marine detritus. I. Field studies on decomposition of the brown alga Sargassum cinereum. J Ag Indian J mar Sci 22: $159-167$

Swain $\Upsilon$, Hillis WE (1959) The phenolic constituents of Prunus domestica. I. The quantitative analysis of phenolic constituents. J Food agric Sci 10:63-68

Valiela l, Wilson J, Buchsbaum R, Rietsma C, Bryant D, Foreman K, Teal J (1984) Importance of chemical composition of salt marsh litter on decay rates and feeding by detritivores. Bull mar Sci 35:261-269

Wilson JO, Buchsbaum R, Valiela I, Swain T (1986) Decomposition in salt marsh ecosystem: phenolic dynamics during decay of litter of Spartina alterniflora. Mar Ecol Prog Ser 29:177-187 